\title{
Evaluation Instruments and Good Practices in Online Education
}

\author{
Sally J. Baldwin \\ Boise State University \\ Jesús Trespalacios \\ Boise State University
}

\begin{abstract}
Chickering and Gamson's (1987) Seven Principles for Good Practice in Undergraduate Education offers extensively researched and validated tenets for best practices in higher education. After a review of the literature, twenty-eight evaluation instruments currently used to design and review online courses in higher education institutions were collected and divided into categories, based on geographical reach and the type of institution for which they were developed. This study investigates how evaluation instruments used in higher education assess the Seven Principles for Good Practice in Undergraduate Education, and what other items are addressed in the evaluation of courses. Findings show that national and statewide evaluation instruments were less institute specific and more closely aligned to the principles of good practice, and that evaluation instruments often measure extraneous items (e.g., student services, navigation, resources, or institutional support). Additional findings and conclusions based on the analysis of the instruments are discussed.
\end{abstract}

Keywords: assessment, best practices, online evaluation, quality

Baldwin, Sally J. \& Trespalacios, Jesús (2017). Evaluation instruments and good practices in online education. Online Learning 21 (2) doi: 10.24059/olj.v21i2.913

\section{Introduction}

Chickering and Gamson (1987) created the Seven Principles for Good Practice in Undergraduate Education as guidelines for effective teaching and learning. Chickering and Gamson’s (1987) principles state that good practice:

1. Encourages student-faculty contact.

2. Encourages cooperation among students.

3. Encourages active learning. 

4. Gives prompt feedback.
5. Emphasizes time on task.
6. Communicates high expectations.
7. Respects diverse talents and ways of learning.

These guidelines represent a philosophy of quality education that has been widely used and accepted for both face-to-face courses and online learning. The Seven Principles have been extensively researched and validated (Institute for Higher Education Policy, 2000; Meyer, 2000; Kuh, 2002; Shea, Pickett, \& Pelz, 2003; Sherry, 2003 (as cited by Dayton \& Vaughn, 2007). The National Institute for Learning Outcomes and each major regional accrediting association support the use of the Seven Principles (Meyer, 2002). Pascarella and Terenzini (1991) have synthesized thousands of research studies informing us about how students learn. Of all these studies, the Seven Principles for Good Practice in Undergraduate Education appear to be "the best known, certainly the most widely distributed” (Cross, 1999, p. 256) framework available about student learning.

The Seven Principles have been successfully used to guide and develop courses in online education. Newlin and Wang (2002) used the Seven Principles to discuss the importance of developing online courses guided by sound pedagogical practice in order to promote quality. In particular, the emphasis on contact between students and instructors was noted as a way to build an online community and prevent isolation of participants. Chickering and Gamson (2002) provided examples of the Seven Principles in practice for the Florida Engineering Education Delivery System to reflect best practices in education. Using the Seven Principles as a guide, Sowan and Jenkins (2013) designed and delivered a hybrid nursing course for 109 undergraduates. The students' satisfaction with the course was measured and compared with a cohort taking the same course face-to-face. The students were very satisfied and had significantly higher scores than the students in the control group. This suggests the effectiveness of applying the Seven Principles to online course design. In an article written for the Institute for Learning Outcomes Assessment, academic administrators at the University of Maryland University College also suggested that the Seven Principles can be used to guide course design (Prineas \& Cini, 2011). The researchers indicated that there is a benefit to using the learner-centered tenets, based on their experience of operating programs serving 67,000 students worldwide. The Seven Principles have been distilled by some researchers into practical advice; Hathaway (2013) analyzed the usefulness of each of the Seven Principles and then provided tips for implementing these principles into online courses. Creasman (2012) offered useful advice to faculty designing online courses to show the benefit of students interacting with faculty: collaborative learning, active learning, instructor social presence, balancing the amount of course information with student commitment and persistence, and providing different learning experiences to engage more students.

Chickering and Gamson's (1987) principles have been used in the past to help evaluate online courses. Bangert (2008) developed an institute-specific student evaluation of online teaching instrument based on the Seven Principles. The purpose of this instrument was to provide instructors with feedback about their online teaching practices. In two studies and with 1,037 students, Bangert measured the validity of the instrument and confirmed the importance of student-faculty interaction, active learning, time on task, and cooperation among students. 
Crews, Wilkinson, and Neill (2015) also formulated an instrument based on the Seven Principles; with 179 students in an undergraduate Computer Applications in Business course at a large southeastern university, they found that what the students valued aligned with the Seven Principles. Drayton and Vaughn (2007) used the Seven Principles as a foundation for a quality assurance checklist they developed to guide the design and assessment of online courses offered by Southern Polytechnic State University (SPSU). The researchers chose the Seven Principles after an extensive literature search and information review on the use of these principles. Billings (2000) adapted the Seven Principles to develop a framework for assessing outcomes and practices in online nursing courses. Çağiltay, Graham, Lim, Craner \& Duffy (2001) used the Seven Principles to evaluate four online courses at Indiana University. To do this, they reviewed course materials and interviewed faculty. Achtemeier, Morris, \& Finnegan (2003) also used the Seven Principles as a basis to assess the evaluation instruments used by higher education institutions in Georgia.

There is a benefit to using an accepted framework like Chickering and Gamson's principles to evaluate education. Standards serve to guide instructional design and delivery by providing a clear understanding of what is expected to attain success. This is a useful practice for course designers and instructors endeavoring to design effective online courses. Malone et al. (1997) indicated the need for well-researched criteria to guide instructional designers and instructors in instructional design models and methods. Gaytan and McEwen (2007) also indicated that using "effective assessment techniques is an essential part of effective teaching and learning” (p. 118) in online courses. Online instruction offers a unique opportunity to strategically direct learners through a framework that reliably leads to the desired result, assuming the course has been created in a manner that identifies and encourages best practices. Given the increasing prevalence of evaluation instruments in distance education, the purpose of this review is to compare Chickering and Gamson's Seven Principles for Good Practice in Undergraduate Education with evaluation instruments currently in use.

\section{Method}

A paper by Achtemeier et al. (2003) guided this research. Achtemeier et al. investigated the definition and principles of effective teaching and learning, specifically in online education. They performed a content analysis of instruments used by the University System of Georgia institutions. Achtemeier et al. identified the Seven Principles for Good Practice in Undergraduate Education as a measurement of good practice, and explored the degree to which evaluation instruments try to assess the Seven Principles for Good Practice in Undergraduate Education. We chose to use the Seven Principles because they have been well researched by others and have stood the test of time since published in 1987. Another benefit of using the Seven Principles is that they represent best practices for higher education, for both traditional and online courses. Thus, the research questions that guide this literature are:

- To what degree do evaluation instruments used in higher education try to assess whether the Seven Principles for Good Practice in Undergraduate Education are taking place?

- What other items are addressed in the instruments to evaluate courses? 
We performed a literature search in the EdITLib: Education \& Information Technology Digital Library, Education Research Complete (EBSCO), ERIC (Education Resources Information Center), and Web of Science and Google Scholar databases utilizing the keywords "Chickering and Gamson," “quality," "assessment," “evaluation,” “online,” and “distance education" to provide information for this research. The purpose of this search was to find literature about the use of assessment/evaluation devices in online education, and to determine what has been written about quality practices in online education. It is important to distinguish between the terms "evaluation” and “assessment." According to Duke University (n.d.), assessment is formative and interested in the process of learning to identify areas of improvement. In contrast, evaluation is used in a summative manner to gauge quality, with an emphasis on the product and an intention to arrive at a final grade or score. Not all of the literature we reviewed followed this distinction so there is some crossover in the use of the two terms.

In a separate search, we collected 33 higher education online course evaluation instruments. We used search terms "course design rubric," "course design checklist," "instructional design rubric," instructional design checklist," "course design standards," "instructional design rubric," and "higher education online course design” on the Internet to look for instruments. Our search was informed by the reference of instruments among evaluation tools we found. For instance, the California State University (CSU) Quality Online Learning and Teaching Rubric (QOLT) listed several rubrics that helped to shape its development (e.g. Quality Matters and Quality Online Course Initiative). Five evaluation instruments were eliminated because they focused only on design and failed to address learning practices. In addition, these instruments, primarily produced by individual bloggers, failed to demonstrate the rigor necessary to be utilized as a complete course evaluation tool. California State University’s Chico’s Rubric for Online Instruction was also eliminated because the California State University (CSU) Quality Online Learning and Teaching Rubric (QOLT) was developed more recently, within the same institutional system. While our sample $(\mathrm{N}=28)$ may seem small, the reach of these instruments is broad (e.g., Quality Matters has more than 900 subscribing institutions, according to the Quality Matters website).

To be included in our study, evaluation instruments had to meet the following criteria: (1) evaluate higher education online course design; (2) support student success; (3) publication after 2000. We divided the evaluation instruments into different categories based on their reach and use: geographical and/or institutional, and level (four- year or two-year). We established a separate category for rubrics from online authors and organizations (Table 1). These categories were determined in part by the example set by Achtemeier et al. (2003), and in part by personal logic. Evaluation instruments created by a national learning management systems company might have a different purpose than an instrument created specifically for a four-year or two-year school. A different level of rigor might be expected based on whether the instrument is used at a national or statewide level, by a four-year institution, a two-year institution, or as an online resource. Our goal was to identify patterns by geographical scope and institutional level. 
Table 1 Evaluation Instruments Sorted by Category

\begin{tabular}{|c|c|}
\hline Categories & Evaluation Instrument \\
\hline $\begin{array}{l}\text { National or } \\
\text { statewide influence: }\end{array}$ & $\begin{array}{l}\text { - Blackboard Exemplary Course Program Rubric } \\
\text { - California State University Quality Online Learning and Teaching } \\
\text { (QOLT) } \\
\text { - Course Design Rubric for the Online Education Initiative (California } \\
\text { Community Colleges) } \\
\text { - Quality Matters (QM) Higher Education Rubric } \\
\text { - Illinois Online Network: Quality Online Course Initiative (QOCI) } \\
\text { - The Open SUNY COTE Quality Review (OSCQR) } \\
\text { - Southern Regional Education Board Checklist for Evaluating Online } \\
\text { Courses }\end{array}$ \\
\hline $\begin{array}{l}\text { Institute specific } \\
\text { (four-year): }\end{array}$ & $\begin{array}{l}\text { - Fayetteville State University Online Course Rubric } \\
\text { - Florida Gulf Coast University Principles of Online Design } \\
\text { - Kansas State E-Learning Quality Checklist } \\
\text { - Pennsylvania State Quality Assurance e-Learning Design Standards } \\
\text { - Rochester Institute of Technology Online Course Design Checklist } \\
\text { - Southern Oregon University Best Practices in Online Course Design } \\
\text { - } \text { and Delivery } \\
\text { - Southern Polytechnic State University Course Assessment Checklist } \\
\text { - University of California Irvine Best Practices in Online Course } \\
\text { - University of New Mexico Online Course Standards Rubric } \\
\text { - University of North Texas Online Course Design Checklist } \\
\text { - Guidelines }\end{array}$ \\
\hline $\begin{array}{l}\text { Institute specific } \\
\text { (two-year): }\end{array}$ & $\begin{array}{l}\text { - Bluegrass Community and Technical College Quality Assurance } \\
\text { Checklist for Online Course Design and Development } \\
\text { - Lewis \& Clark College Checklist for Instructor Review of Online } \\
\text { and Hybrid Course Design } \\
\text { - Northeast Community College (NEEC) Rubric for Online Course } \\
\text { Design Standards } \\
\text { - Palomar Online Course Best Practices Checklist } \\
\text { - Portland Community College Online Course Development Guide } \\
\text { - Three Rivers Community College Online Course Design Review }\end{array}$ \\
\hline $\begin{array}{l}\text { Online professional } \\
\text { development: }\end{array}$ & $\begin{array}{l}\text { - Online Learning Consortium Quality Scorecard } 2014 \\
\text { - EdTech Leaders Online Course Elements (Educational Development } \\
\text { Center, Inc.) } \\
\text { - Learning Resource Network (LERN) Online Course Best Practices } \\
\text { Checklist }\end{array}$ \\
\hline
\end{tabular}


The instruments were analyzed in terms of content, development process, scope, and application. A coding scheme was developed to determine whether an evaluation instrument met the criteria to be evaluated. This scheme was based on information from our literature review of examples of the Seven Principles of Good Practice in online education. Standards and criteria within each evaluation instrument were analyzed and coded to identify principles of good practice that had been addressed using the scheme presented in Table 2. We looked for items that utilized the same or similar terms as the Seven Principles or for examples based on the Seven Principles' intent. For instance, while many evaluation instruments mentioned feedback to students, only evaluation instruments that actually mentioned "prompt feedback" or gave a time requirement (e.g., “48 hours”) were coded as assessing prompt feedback. When in doubt, we referred to the examples provided by Chickering \& Ehrmann (1996) for implementing the principles using technology. We also referred to Watwood, Nugent, \& Deihl (2009), who provided vignettes and supporting material to illustrate the Seven Principles in online teaching.

Table 2 Coding Scheme

\begin{tabular}{|c|c|}
\hline $\begin{array}{l}\text { Seven Principles of Good } \\
\text { Practice } \\
\end{array}$ & Coding Example \\
\hline 1. Student-Faculty Contact & $\begin{array}{l}\text { "Students have an opportunity to get to know the instructor"(Open } \\
\text { SUNY’s Center for Online Teaching Excellence, 2016). }\end{array}$ \\
\hline $\begin{array}{l}\text { 2. Cooperation Among } \\
\text { Students }\end{array}$ & $\begin{array}{l}\text { "Opportunities/tools are provided to encourage student-student } \\
\text { collaboration (i.e., web conferencing, instant messaging, etc." } \\
\text { (Online Learning Consortium Quality Scorecard 2014 Handbook: } \\
\text { Criteria for Excellence in the Administration of Online Programs, } \\
\text { 2014, p. 38). }\end{array}$ \\
\hline 3. Active Learning & $\begin{array}{l}\text { "The course instruction includes activities that engage students in } \\
\text { active learning." (SREB Checklist for Evaluation Online Courses, } \\
\text { 2006, p. 6). }\end{array}$ \\
\hline 4. Prompt Feedback & $\begin{array}{l}\text { "Respond to students' emails within } 24 \text { hours during weekdays and } \\
\text { within one working day on holidays and weekends" (Southern } \\
\text { Oregon University, Best Practices in Online Course Design and } \\
\text { Delivery, 2009, p. 9). }\end{array}$ \\
\hline 5. Time on Task & $\begin{array}{l}\text { "Communicated time requirements clearly. Deliverables, weekly } \\
\text { activities, readings, projects, discussions were all placed within } \\
\text { the appropriate time requirements with unambiguous expectations } \\
\text { and instructions. Expenditures of time were given for the activities } \\
\text { both for minimum and maximum achievement. Stressed } \\
\text { repeatedly to students the amounts of time needed to accomplish } \\
\text { every exercise or assignment." (Southern Polytechnic State } \\
\text { University, n.d., p.4). }\end{array}$ \\
\hline 6. High Expectations & $\begin{array}{l}\text { "Grading rubrics and models of partially to fully completed } \\
\text { assignments are provided to the teacher" (SREB Checklist for } \\
\text { Evaluating Online Courses, 2006, p. 9). }\end{array}$ \\
\hline $\begin{array}{l}\text { 7. Diverse Talents and } \\
\text { Ways of Learning }\end{array}$ & $\begin{array}{l}\text { "A variety of instructional delivery methods, accommodating } \\
\text { multiple learning styles are available throughout the } \\
\text { course"(Quality Online Course Initiative Rubric, Illinois Online } \\
\text { Network, University of Illinois, 2010, p. 1). }\end{array}$ \\
\hline
\end{tabular}




\section{Findings}

The number of instruments addressing each principle has been summarized in Table 3. In the review of the evaluation instruments, student-faculty contact and cooperation among students were the two principles most frequently assessed. Active learning was also frequently evaluated. Much less frequently measured (in order), were diverse talents and ways of learning, prompt feedback, and high expectations. Only one evaluation instrument included student's time on task.

Table 3 Number of Evaluation Instruments Assessing the Seven Principles of Good Practice

\begin{tabular}{|l|c|c|c|c|c|c|c|c|}
\hline $\begin{array}{l}\text { Seven } \\
\text { Principles of } \\
\text { Good } \\
\text { Practice }\end{array}$ & $\begin{array}{c}\text { Student- } \\
\text { Faculty } \\
\text { Contact }\end{array}$ & $\begin{array}{c}\text { Cooperation } \\
\text { Among } \\
\text { Students }\end{array}$ & $\begin{array}{c}\text { Active } \\
\text { Learning }\end{array}$ & $\begin{array}{c}\text { Prompt } \\
\text { Feedback }\end{array}$ & $\begin{array}{c}\text { Time } \\
\text { on } \\
\text { Task }\end{array}$ & $\begin{array}{c}\text { High } \\
\text { Expectations }\end{array}$ & $\begin{array}{c}\text { Diverse } \\
\text { Talents } \\
\text { and Ways } \\
\text { of } \\
\text { Learning }\end{array}$ & Percent \\
\hline $\begin{array}{l}\text { National or } \\
\text { Statewide } \\
\text { (N=7) }\end{array}$ & 6 & 6 & 4 & 3 & 1 & 2 & 4 & $51 \%$ \\
\hline $\begin{array}{l}\text { Institute } \\
\text { specific (4- } \\
\text { year) (N=12) }\end{array}$ & 11 & 8 & 10 & 4 & 1 & 1 & 4 & $45 \%$ \\
\hline $\begin{array}{l}\text { Institute } \\
\text { specific (2- } \\
\text { year) (N=6) }\end{array}$ & 5 & 5 & 1 & 1 & & & & \\
\hline $\begin{array}{l}\text { Online } \\
\text { professional } \\
\text { development } \\
\text { (N=3) }\end{array}$ & 3 & 2 & 1 & & & & & $33 \%$ \\
\hline Percent & $89 \%$ & $75 \%$ & $57 \%$ & $29 \%$ & $4 \%$ & $14 \%$ & $36 \%$ & \\
\hline
\end{tabular}

National or statewide evaluation instruments were found to assess a greater percentage of the Seven Principles than the other categories. For example, the Quality Matters (QM) rubric is part of a subscription-based program that involves professional training. Annually, a committee reviews independent scholarly research related to online course design as part of the information that helps inform the criteria of the QM rubric (Shattuck, 2013). The QM organization boasts "825 subscribing educational institutions and 160 individual subscribers" (Shattuck, Zimmerman, \& Adair, 2015, p. 26) and is considered the most pervasive tool used to evaluate higher education course quality.

While none of these instruments addressed all of the principles, two of the instruments (Open SUNY COTE Quality Review and Southern Regional Educational Board Checklist for Evaluating Online Courses) assessed substantially more of the principles than other instruments (Table 4). Other issues that were frequently addressed in this group of instruments include ensuring that navigation is intuitive, incorporating intended outcomes for students, utilizing assessment, and including support for students. 
Table 4 Number of Seven Principles of Good Practice Assessed by National or Statewide Evaluation Instruments

\begin{tabular}{|c|c|c|c|c|c|c|c|c|}
\hline $\begin{array}{l}\text { Seven } \\
\text { Principles of } \\
\text { Good Practice } \\
\end{array}$ & $\mid \begin{array}{c}\text { Student } \\
- \\
\text { Faculty } \\
\text { Contact }\end{array}$ & $\begin{array}{l}\text { Cooperation } \\
\text { Among } \\
\text { Students }\end{array}$ & $\begin{array}{c}\text { Active } \\
\text { Learning }\end{array}$ & $\begin{array}{c}\text { Prompt } \\
\text { Feedback }\end{array}$ & $\begin{array}{l}\text { Time } \\
\text { on } \\
\text { Task }\end{array}$ & $\begin{array}{c}\text { High } \\
\text { Expectations }\end{array}$ & \begin{tabular}{|c|} 
Diverse \\
Talents \\
and \\
Ways of \\
Learning \\
\end{tabular} & Percent \\
\hline \begin{tabular}{|l|} 
Blackboard \\
Exemplary \\
Course Program \\
Rubric \\
\end{tabular} & X & X & X & & & & & $43 \%$ \\
\hline $\begin{array}{l}\text { CSU Quality } \\
\text { Online Learning } \\
\text { \& Teaching } \\
\text { (QOLT) }\end{array}$ & X & X & & & & & X & $43 \%$ \\
\hline $\begin{array}{l}\text { Course Design } \\
\text { Rubric for the } \\
\text { Online } \\
\text { Education } \\
\text { Initiative } \\
\text { (California } \\
\text { Community } \\
\text { Colleges) }\end{array}$ & X & X & & X & & X & & $57 \%$ \\
\hline $\begin{array}{l}\text { Quality Matters } \\
\text { Higher } \\
\text { Education } \\
\text { Rubric (QM) } \\
\end{array}$ & & & X & & & & & $14 \%$ \\
\hline $\begin{array}{l}\text { Illinois Online } \\
\text { Network: } \\
\text { Quality Online } \\
\text { Course } \\
\text { Initiative Rubric } \\
\text { (QOCI) } \\
\end{array}$ & X & X & & & & & X & $43 \%$ \\
\hline $\begin{array}{l}\text { The Open } \\
\text { SUNY COTE } \\
\text { Quality Review } \\
\text { (OSCQR) }\end{array}$ & X & X & X & X & & & X & $71 \%$ \\
\hline $\begin{array}{l}\text { Southern } \\
\text { Regional } \\
\text { Educational } \\
\text { Board Checklist } \\
\text { for Evaluating } \\
\text { Online Courses }\end{array}$ & X & X & X & X & & X & X & $86 \%$ \\
\hline & $86 \%$ & $86 \%$ & $57 \%$ & $43 \%$ & $0 \%$ & $29 \%$ & $57 \%$ & $51 \%$ \\
\hline
\end{tabular}


The only evaluation instrument examined that assessed all of the Seven Principles was the Southern Polytechnic State University Reviewers Rubric (Table 5). This instrument was adapted from Chickering \& Ehrmann's Implementing the Seven Principles: Technology as Lever (1996), and the principles clearly served as the framework for the institution's instrument. Providing students with clear goals and objectives, ensuring that assessment measures these objectives, and stipulating resources and institutional support for students were items frequently addressed by four-year, institute-specific evaluation instruments.

Table 5 Number of Seven Principles of Good Practice Assessed by Institute Specific (Four-Year) Evaluation Instruments

\begin{tabular}{|c|c|c|c|c|c|c|c|c|}
\hline $\begin{array}{l}\text { Seven } \\
\text { Principles } \\
\text { of Good } \\
\text { Practice }\end{array}$ & $\mid \begin{array}{c}\text { Student } \\
- \\
\text { Faculty } \\
\text { Contact }\end{array}$ & $\begin{array}{c}\text { Cooperation } \\
\text { Among } \\
\text { Students }\end{array}$ & $\begin{array}{c}\text { Active } \\
\text { Learning }\end{array}$ & $\begin{array}{c}\text { Prompt } \\
\text { Feedback }\end{array}$ & $\begin{array}{l}\text { Time } \\
\text { on } \\
\text { Task }\end{array}$ & $\begin{array}{c}\text { High } \\
\text { Expectations }\end{array}$ & \begin{tabular}{|c} 
Diverse \\
Talents \\
and \\
Ways of \\
Learning
\end{tabular} & Percent \\
\hline $\begin{array}{l}\text { Fayetteville } \\
\text { State } \\
\text { University } \\
\text { Online } \\
\text { Course } \\
\text { Rubric }\end{array}$ & $\mathrm{X}$ & $\mathrm{X}$ & & & & & $X$ & $43 \%$ \\
\hline $\begin{array}{l}\text { Florida Gulf } \\
\text { Coast } \\
\text { University } \\
\text { Principles of } \\
\text { Online } \\
\text { Design } \\
\text { Checklist }\end{array}$ & $\mathrm{X}$ & $X$ & $\mathrm{X}$ & & & & & $43 \%$ \\
\hline \begin{tabular}{|l|} 
Kansas State \\
E-Learning \\
Quality \\
Checklist
\end{tabular} & $\mathrm{X}$ & $\mathrm{X}$ & & & & & $\mathrm{X}$ & $43 \%$ \\
\hline $\begin{array}{l}\text { Pennsylvania } \\
\text { State Quality } \\
\text { Assurance e- } \\
\text { Learning } \\
\text { Design } \\
\text { Standards } \\
\end{array}$ & & & $\mathrm{X}$ & & & & & $14 \%$ \\
\hline \begin{tabular}{|l|} 
Rochester \\
Institute of \\
Technology \\
Online \\
Course \\
Design \\
Checklist
\end{tabular} & $X$ & & X & & & & & $29 \%$ \\
\hline
\end{tabular}




\begin{tabular}{|c|c|c|c|c|c|c|c|c|}
\hline \begin{tabular}{|l|} 
Southern \\
Oregon \\
University \\
\end{tabular} & $X$ & $X$ & $X$ & $X$ & & & & $57 \%$ \\
\hline \begin{tabular}{|l} 
Southern \\
Polytechnic \\
State \\
University \\
\end{tabular} & $X$ & $X$ & $X$ & $X$ & $X$ & $X$ & $X$ & $100 \%$ \\
\hline $\begin{array}{l}\text { University of } \\
\text { California } \\
\text { Irvine Best } \\
\text { Practices in } \\
\text { Online } \\
\text { Course } \\
\text { Design } \\
\end{array}$ & $X$ & & $X$ & & & & & $29 \%$ \\
\hline $\begin{array}{l}\text { University of } \\
\text { New Mexico } \\
\text { Online } \\
\text { Course } \\
\text { Standards } \\
\text { Rubric } \\
\end{array}$ & $X$ & $X$ & $X$ & $X$ & & & & $57 \%$ \\
\hline $\begin{array}{l}\text { University of } \\
\text { North Texas } \\
\text { Online } \\
\text { Course } \\
\text { Design } \\
\text { Checklist } \\
\end{array}$ & $X$ & & $X$ & & & & & $29 \%$ \\
\hline $\begin{array}{l}\text { University of } \\
\text { Wisconsin- } \\
\text { La Crosse } \\
\text { Online } \\
\text { Course } \\
\text { Evaluation } \\
\text { Guidelines } \\
\end{array}$ & $X$ & $X$ & $X$ & $X$ & & & & $57 \%$ \\
\hline \begin{tabular}{|l|} 
Utah State \\
Online \\
Course \\
Quality \\
Rubric \\
\end{tabular} & $X$ & $X$ & $X$ & & & & & $43 \%$ \\
\hline & $92 \%$ & $67 \%$ & $83 \%$ & $33 \%$ & $8 \%$ & $8 \%$ & $25 \%$ & $45 \%$ \\
\hline
\end{tabular}

Two-year, institute-specific evaluation instruments were considerably less likely to assess the Seven Principles of Good Practice (Table 6). Most institutions assessed only two principles (student-faculty contact and cooperation among students). Active learning, prompt feedback, and diverse talents and ways of learning were rarely mentioned. Instead, the two-year institutes' evaluation tools often focused on accessibility, organization and presentation of content, technical usability, presence of syllabus, use of assessment and student support. 
Table 6 Number of Seven Principles of Good Practice Assessed by Institute Specific (Two-Year) Evaluation Instruments

\begin{tabular}{|c|c|c|c|c|c|c|c|c|}
\hline $\begin{array}{l}\text { Seven } \\
\text { Principles of } \\
\text { Good } \\
\text { Practice } \\
\end{array}$ & $\begin{array}{l}\text { Student- } \\
\text { Faculty } \\
\text { Contact }\end{array}$ & $\begin{array}{c}\text { Cooperation } \\
\text { Among } \\
\text { Students }\end{array}$ & $\begin{array}{c}\text { Active } \\
\text { Learning }\end{array}$ & $\begin{array}{c}\text { Prompt } \\
\text { Feedback }\end{array}$ & $\begin{array}{c}\text { Time } \\
\text { on } \\
\text { Task }\end{array}$ & $\begin{array}{c}\text { High } \\
\text { Expectations }\end{array}$ & \begin{tabular}{|c|c} 
Diverse \\
Talents \\
and \\
Ways of \\
Learning
\end{tabular} & Percent \\
\hline \begin{tabular}{|l} 
Bluegrass \\
Community \\
and Technical \\
College \\
Quality \\
Assurance \\
Checklist for \\
Online Course \\
Design and \\
Development
\end{tabular} & X & & & & & & & $14 \%$ \\
\hline $\begin{array}{l}\text { Lewis \& } \\
\text { Clark College } \\
\text { Checklist for } \\
\text { Instructor } \\
\text { Review of } \\
\text { Online and } \\
\text { Hybrid } \\
\text { Course } \\
\text { Design }\end{array}$ & X & X & X & X & & & X & $57 \%$ \\
\hline $\begin{array}{l}\text { Northeast } \\
\text { Community } \\
\text { College } \\
\text { (NEEC) } \\
\text { Rubric for } \\
\text { Online Course } \\
\text { Design } \\
\text { Standards } \\
\end{array}$ & & $\mathrm{X}$ & & & & & & $14 \%$ \\
\hline $\begin{array}{l}\text { Palomar } \\
\text { Online Course } \\
\text { Best Practices } \\
\text { Checklist } \\
\end{array}$ & X & $\mathrm{X}$ & & & & & & $29 \%$ \\
\hline $\begin{array}{l}\text { Portland } \\
\text { Community } \\
\text { College } \\
\text { Online Course } \\
\text { Development } \\
\text { Guide } \\
\end{array}$ & $\mathrm{X}$ & $\mathrm{X}$ & $X$ & & & & & $43 \%$ \\
\hline
\end{tabular}




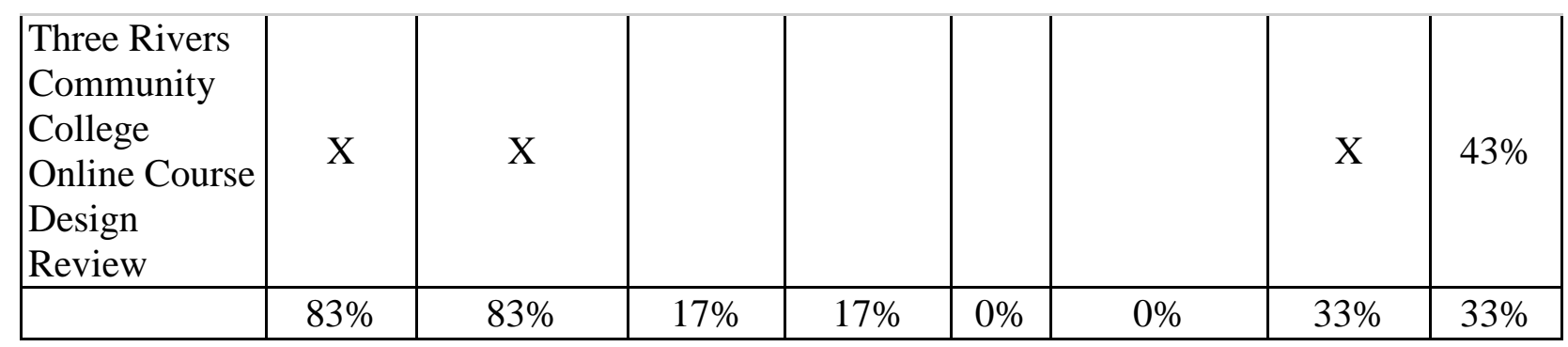

The number of online professional development evaluation instruments that assessed the Seven Principles of Good Practice was below the mean (Table 7). While each of the instruments included student-faculty contact, none of the instruments included prompt feedback or time on task. The online professional development evaluation instruments focused on items like course navigation, scalability of assignments, use of media in the course, ongoing assessments, and clear instructions. The Online Learning Consortium was recently awarded $\$ 2.5$ million by the Bill and Melinda Gates Foundation to foster best practices in post-secondary learning. In particular, the grant will support expansion of the OLC Quality Scorecard and fund a new competition to "recognize and reward exemplar institutions and faculty for effective use of digital courseware" (Online Learning Consortium, 2015). Special emphasis will be added to the scorecard to include steps that focus on attributes that help "minority, first-generation, lowincome or other disadvantaged backgrounds” (Online Learning Consortium, 2015). This example draws attention to how funding from grants and member institution goals can have a large impact on evaluation instruments.

Table 7 Number of Seven Principles of Good Practice Assessed by Online Professional Development Evaluation Instruments

\begin{tabular}{|c|c|c|c|c|c|c|c|c|}
\hline $\begin{array}{l}\text { Seven } \\
\text { Principles } \\
\text { of Good } \\
\text { Practice }\end{array}$ & $\begin{array}{l}\text { Student- } \\
\text { Faculty } \\
\text { Contact }\end{array}$ & $\begin{array}{c}\text { Cooperatio } \\
\text { n Among } \\
\text { Students }\end{array}$ & $\begin{array}{c}\text { Active } \\
\text { Learning }\end{array}$ & $\begin{array}{c}\text { Prompt } \\
\text { Feedback }\end{array}$ & $\begin{array}{c}\text { Time } \\
\text { on } \\
\text { Task }\end{array}$ & $\begin{array}{c}\text { High } \\
\text { Expectations }\end{array}$ & \begin{tabular}{|c|} 
Diverse \\
Talents \\
and \\
Ways of \\
Learning
\end{tabular} & Percent \\
\hline $\begin{array}{l}\text { Online } \\
\text { Learning } \\
\text { Consortium } \\
\text { Quality } \\
\text { Scorecard }\end{array}$ & X & X & X & & & X & & $57 \%$ \\
\hline $\begin{array}{l}\text { EdTech } \\
\text { Leaders } \\
\text { Online } \\
\text { Course } \\
\text { Elements }\end{array}$ & X & $\mathrm{X}$ & & & & & X & $43 \%$ \\
\hline $\begin{array}{l}\text { Learning } \\
\text { Resource } \\
\text { Network } \\
\text { (LERN) } \\
\text { Online } \\
\text { Course Best }\end{array}$ & X & & & & & & & $14 \%$ \\
\hline
\end{tabular}




\begin{tabular}{|l|l|l|l|l|l|l|l|l|}
\hline $\begin{array}{l}\text { Practices } \\
\text { Checklist }\end{array}$ & & & & & & & & \\
\hline & $100 \%$ & $67 \%$ & $33 \%$ & $0 \%$ & $0 \%$ & $33 \%$ & $33 \%$ & $38 \%$ \\
\hline
\end{tabular}

\section{Conclusions}

Creating a course involves many elements. But Chickering and Gamson have emphasized seven principles of good practice which have been widely cited and used over the past 25 years. Our findings indicate that higher education assessment tools are not adequately evaluating all of these well-established principles of effective practice. Most of the evaluation instruments we reviewed assess for student-faculty contact (85\%), cooperation among students (75\%), and active learning (57\%). The more broadly used evaluation instruments (i.e., national or statewide compared to instruments from two-year colleges) were more likely to assess for a greater number of the Seven Principles. There is a system-wide deficiency, however. The majority of instruments we reviewed did not assess for prompt feedback (29\%) or for time on task (4\%), a practice of ensuring that students understand time requirements and deadlines. Most of the evaluation instruments also fail to assess for communicating high expectations (14\%). High expectations can be communicated by assigning challenging work, providing examples, and publically praising exemplary results (Watwood et al., 2009). These practices help ensure quality in online learning by clarifying and illustrating expectations to learners.

While the evaluation instruments often failed to cover some of the seven basic principles, this was not due to their brevity. In fact, they were quite long; the average instrument we reviewed featured over seven standards and 53 specific criteria. We found that many of the evaluation instruments measured the use of learning assessments, clear course organization and presentation, and the presence of course goals and objectives. Clear navigation was also noted frequently, as was availability of resources for student support. These items may be important but they are not part of the crucial seven principles linked to good practice. Adding the Seven Principles to these instruments may encourage best practice but may also create instruments that are increasingly onerous to use. Conversely, adding additional items to the Seven Principles may dilute the focus and distract the practitioner's emphasis from providing a quality education based on best practices.

A limitation of the study was that we did not collect evaluation instruments from sources other than the Internet, and we examined only evaluation instruments that were written in English and publicly available. Furthermore, we did not have contact with any of the institutions or creators of the evaluation instruments. Additional studies might be undertaken to solicit rubrics from institutions and organizations. Chickering and Gamson (1999) worked to produce a framework that was "accessible, understandable, practical, and widely applicable” (p. 76). Future studies could also investigate the use of a rubric that assesses for the Seven Principles and its impact on student satisfaction and learning. 


\section{References}

Achtemeier, S. D., Morris, L. V., \& Finnegan, C. L. (2003). Considerations for developing evaluations of online courses. Journal of Asynchronous Learning Networks, 7(1), 1-13.

Bangert, A. W. (2008) The development and validation of the student evaluation of online teaching effectiveness, Computers in the Schools, 25(1)2, 25-47. doi:10.1080/07380560802157717

Billings, D. M. (2000). A framework for assessing outcomes and practices in web-based courses in nursing. Journal of Nursing Education, 39(2), 60-67.

Blackboard. (2012). Blackboard exemplary course program rubric. Retrieved from http://www.blackboard.com/getdoc/7deaf501-4674-41b9-b2f2-554441ba099b/2012blackboard-exemplary-course-rubric.aspx

Bluegrass Community and Technical College. (2011, April 13). Quality assurance checklist for online course design and development. Retrieved from http://district.bluegrass.kctcs.edu/ben.worth/distance_learning/QA_Checksheet.pdf

Çağiltay, K., Graham, C. R., Lim, B. R., Craner, J., \& Duffy, T. M. (2001). The seven principles of good practice: A practical approach to evaluating online courses. Hacettepe Üniversitesi Eğitim Fakültesi Dergisi, 20(20).

California Community College Online Education Initiative. (2016). Course design rubric for the online education initiative. Retrieved from http://ccconlineed.org/wpcontent/uploads/2016/11/OEI_CourseDesignRubric_Nov2016-3.pdf

California State University. (2015). Quality online learning and teaching rubric. Retrieved from http://courseredesign.csuprojects.org/wp/wp-content/uploads/2013/11/QOLT-QMAlignment-Matrix-.pdf

California State University, Chico. (2015). Welcome to the exemplary online instruction (EOI) website. Retrieved from http://www.csuchico.edu/eoi/http://sphweb.bumc.bu.edu/otlt/teachingLibrary/Technology /seven_principles.pdf

Chickering, A. W., \& Ehrmann, S. C. (1996). Implementing the seven principles: Technology as lever. AAHE bulletin, 49, 3-6. Retrieved from http://sphweb.bumc.bu.edu/otlt/teachingLibrary/Technology/seven_principles.pdf

Chickering, A. W., \& Gamson, Z. F. (1987). Seven principles for good practice in undergraduate education. AAHE bulletin, $3,7$. 
Chickering, A. W., \& Gamson, Z. F. (1999). Development and adaptations of the seven principles for good practice in undergraduate education. New Directions for Teaching and Learning, 1999(80), 75-81.

Chickering, A. W., \& Gamson, Z. F. (2002). Seven principles of good practice: A FEEDS Evaluation.

Creasman, P. A. (2012). Considerations in online course design. IDEA paper, 52.

Crews, T. B., Wilkinson, K., \& Neill, J. K. (2015). Principles for good practice in undergraduate education: Effective online course design to assist students' success. Journal of Online Learning and Teaching, 11(1), 87.

Cross, K. P. (1999). What do we know about students' learning, and how do we know it? Innovative Higher Education, 23(4).

Dayton, D., \& Vaughn, M. M. (2007). Developing a quality assurance process to guide the design and assessment of online courses. Technical Communication, 54(4), 475-489.

Duke University. (n.d.). What is the difference between assessment and evaluation? Retrieved from http://arc.duke.edu/documents/The\%20difference\%20between\%20assessment\%20and\%2 0evaluation.pdf

Educational Development, Inc. (2015). EdTech leaders online course elements. Retrieved from http://courses.edtechleaders.org/documents/OCD/Course_Dev_Check.htm

Fayetteville State University. (2015). Planning and developing new online programs. Office of Faculty Development. Retrieved from http://www.uncfsu.edu/facultydevelopment/faculty-services

Florida Gulf Coast University. (2006). Principles of online design checklist. Faculty Development and Support. Retrieved from http:/www.fgcu.edu/onlinedesign/Intro.html

Gaytan, J., \& McEwen, B. C. (2007). Effective online instructional and assessment strategies. The American Journal of Distance Education, 21(3), 117-132.

Hathaway, K. L. (2013). An application of the seven principles of good practice to online courses. Research in Higher Education Journal, 22, 1.

Illinois Online Network. (2010). Quality online course initiative rubric \& checklist. University of Illinois. Retrieved from http://www.ion.uillinois.edu/initiatives/qoci/rubric.asp

Kansas State University. (2013). Kansas State e-learning quality checklist. Retrieved from http://elearningfacultymodules.org/uploaded/QualityELearningChecklist.pdf 
Learning Resource Network (LERN). (2015). Online course best practices checklist. Retrieved from http://teachingonthenet.org/best-practices-standards.cfm

Lewis and Clark Community College (2012). Checklist for instructor review of online and hybrid course design. Retrieved from

http://www.lc.edu/uploadedFiles/Pages/Audiences/Online\%20Course\%20Review\%20Ch ecklist.pdf

Malone, B. G., Malm, L. D., Nay, F. W., Oliver, B. E., Saunders, N. G., \& Thompson, J. C. (1997). Observation of instruction via distance learning: The need for a new evaluation paradigm. Paper presented at the Annual Meeting of the Midwestern Educational Research Association, Chicago, Illinois.

Meyer, K. A. (2002, January 1). Quality in distance education: Focus on online learning. ASHEERIC Higher Education Report. San Francisco, CA: Jossey-Bass Higher and Adult Education Series.

Newlin, M. H., \& Wang, A. Y. (2002). Integrating technology and pedagogy: Web instruction and seven principles of undergraduate education. Teaching of Psychology, 29(4), 325330.

Northeast Community College. (n.d.). NECC rubric for online course design standards. Retrieved from http://www.northeast.edu/About-Us/Accreditation/References/BasicDesign-Standards-for-Online-Courses.pdf

Online Learning Consortium. (2015). Home. Retrieved from http://onlinelearningconsortium.org

Palomar College. (2012). Online course best practices checklist. Academic Technology Committee. Retrieved from http://www2.palomar.edu/poet/BestPracticesChecklistSP12.pdf

Pascarella, E. T., \& Terenzini, P. T. (1991). How college affects students. San Francisco, CA: Jossey-Bass.

Pickett, A. M. (2009). SUNY learning network rubric for formal course review of new online faculty/courses. Retrieved from http://wiki.sln.suny.edu/download/attachments/4032379/Course_Review_Rubric.pdf?ver sion $=1 \&$ modificationDate $=1277483875246$

Portland Community College. (2015). Portland Community College online course development guide. Retrieved from http://www.pcc.edu/about/distance/faculty/development/coursedevelopment-questionnaire/

Prineas, M., \& Cini, M. (2011). Assessing learning in online education: the role of technology in improving student outcomes. National Institute for Learning Outcomes Assessment. Retrieved from http://www.learningoutcomeassessment.org/occasionalpapertwelve.htm 
Rochester Institute of Technology. (2014) Online course design checklist. Retrieved from https://www.rit.edu/academicaffairs/tls/sites/rit.edu.academicaffairs.tls/files/docs/RIT\%2 0Online\%20Design\%20Checklist_Jul2014_v1.pdf

Southern Oregon Distance Education Center. (2010, September 10). Best practice in online course design delivery. Southern Oregon University. Retrieved from http://www.sou.edu/distancelearning/SOU\%20DEC\%20Best\%20Practices.pdf

Southern Polytechnic State University (n.d.). Kennesaw State University. Retrieved from http://www.kennesaw.edu

Southern Regional Education Board. (2006). SREB checklist for evaluating online courses. Retrieved from http://publications.sreb.org/2006/06T06_Checklist_for_EvaluatingOnline-Courses.pdf

Sowan, A. K., \& Jenkins, L. S. (2013). Use of the seven principles of effective teaching to design and deliver an interactive hybrid nursing research course. Nursing Education Perspectives, 34(5), 315-22.

State University of New York. (2016). Open COTE SUNY quality rubric. The Center for Online Center Excellence. Retrieved from https://bbsupport.sln.suny.edu/bbcswebdav/institution/OSCQR/OSCQR\%20Assets/OSC QR\%203rd\%20Edition.pdf

The Pennsylvania State University. (2015). Penn State quality assurance e-learning design standards. Web Learning @ Penn State. Retrieved from https://weblearning.psu.edu/resources/penn-state-online-resources/qualityassurance/

Three Rivers Community College. (n.d.) Three Rivers Community College online course design checklist. Retrieved from http://www.threerivers.edu/Div_IT/EducationalTechnology/PDF/OnlineCourseReviewCh ecklist.pdf

University of California, Irvine. (2012). Best practices in online course design. UC Irvine, Teaching, Learning \& Technology Center. Retrieved from http://www.tltc.uci.edu/pdf/BEST\%20PRACTICES_2.pdf

University of New Mexico. (2015, May 1). Online course standards rubric. Retrieved from http://newmedia.unm.edu/common/documents/OnlineCourseStandardsRubric.pdf

University of North Texas. (2012, April 12). UNT online course design checklist. Retrieved from https://clear.unt.edu/sites/default/files/UNTcourse_design_checklist_rev4_12.pdf 
University of Wisconsin - La Crosse. (2014, May 23). UW-La Crosse online course evaluation guidelines. Retrieved from

http://www.uwlax.edu/uploadedFiles/Academics/online/guidelines.pdf

Utah State. University. (n.d.). Utah State online course quality rubric. Retrieved from https://elearn.usu.edu/courses/online-rubric-form.pdf

Watwood, B., Nugent, L., \& Deihl, W. (2009). Building from content to community: Rethinking the transition to online teaching and learning: A CTE White Paper. Richmond, VA: Virginia Commonwealth University: Center for Teaching Excellence. 